\title{
The Problem of Online Learning in Islamic Primary School in Yogyakarta
}

\author{
Nana Apriliana ${ }^{1}$ \\ ${ }^{1}$ Yogyakarta State University \\ 1nurrohmatnana@gmail.com
}

\begin{abstract}
In the rapid development of religion-based schools in Indonesia, especially Islam, this study intended to determine the problems experienced by students, parents, and teachers in Islamic primary school (Madrasah Ibtidaiyah) during online learning due to the pandemic Covid-19. This was a descriptive study using the online survey method. The data was collected using online openended questionnaires to 136 participants of elementary school students, parents, and teachers. It was found that students preferred play to study, they were lack of discipline in learning and felt bored studying at home. Whereas, the entire phone's memory, unstable internet connection, and lack of budget for internet connection were the most obstacle factors faced by parents and teachers. The teachers also had unlimited working time. Parents were also challenging to explain the materials for their children, challenging to build students' motivation, difficult to divide the time between work and guide their children to study. Therefore, the researcher recommends (1) applying learning rules to discipline students learning activities during online learning, (2) consulting with teachers or find appropriate sources to explain difficult materials i.e. free access to online learning media provided by the Ministry of Education and Culture (MoEC) to enrich learning sources, (3) creating a comfortable learning atmosphere, trying to learn outdoor and interspersed with fun activities are essential methods to kill children boredom in online learning, and (4) equipping teachers with online learning skills i.e. the use of technology, software, and teaching online method in long term teacher education program (Pendidikan Profesi Guru/PPG) to improve teachers' teaching quality in online teaching.
\end{abstract}

\section{Keywords: Islamic Primary School, Obstacles, Online Learning}

\begin{abstract}
Abstrak
Dalam pesatnya perkembangan sekolah berbasis agama di Indonesia khususnya Islam, penelitian ini dimaksudkan untuk mengetahui permasalahan yang dialami siswa, orang tua, dan guru di sekolah dasar Islam (Madrasah Ibtidaiyah) selama pembelajaran online akibat pandemi Covid-19. Jenis penelitian deskriptif dengan metode survei online. Pengumpulan data dilakukan dengan menggunakan kuesioner terbuka online kepada 136 partisipan siswa, orang tua, dan guru sekolah dasar. Ditemukan bahwa siswa lebih suka bermain daripada belajar, mereka kurang disiplin dalam belajar dan merasa bosan belajar di rumah. Sedangkan permasalahan tentang memori
\end{abstract}


ponsel yang penuh, koneksi internet yang tidak stabil, dan minimnya anggaran untuk koneksi internet menjadi faktor penghambat terbesar yang dihadapi oleh orang tua dan guru. Para guru juga memiliki waktu kerja yang tidak terbatas. Orang tua juga sulit menjelaskan materi kepada anaknya, sulit membangun motivasi belajar siswa, sulit membagi waktu antara pekerjaan dan membimbing anaknya untuk belajar. Oleh karena itu, peneliti merekomendasikan (1) penerapan aturan pembelajaran untuk mendisiplinkan kegiatan belajar siswa selama pembelajaran online, (2) berkonsultasi dengan guru atau mencari sumber yang tepat untuk menjelaskan materi yang sulit yaitu akses gratis media pembelajaran online yang disediakan oleh Kementerian Pendidikan dan Kebudayaan (Kemdikbud) untuk memperkaya sumber belajar, (3) menciptakan suasana belajar yang nyaman, mencoba belajar di luar ruangan dan diselingi dengan kegiatan yang menyenangkan merupakan metode penting untuk mengurangi kebosanan anak dalam pembelajaran online, dan (4) membekali guru dengan keterampilan belajar online yaitu penggunaan teknologi, perangkat lunak, dan metode pengajaran online dalam program pendidikan guru jangka panjang (Pendidikan Profesi Guru / PPG) untuk meningkatkan kualitas pengajaran guru dalam pengajaran online.

Kata Kunci: Hambatan, Pembelajaran Online, Sekolah Dasar Islam

\section{Introduction}

Since the beginning of 2020, the world has been shocked by the Corona Virus Disease (Covid-19) outbreak which has infected almost all countries in the world. All segments are affected, including Education. Education is the key element to build a good nation. ${ }^{1}$ The Covid-19 pandemic has indeed pushed the world to a standstill affecting the education sector tremendously. ${ }^{2}$ The tremendous education sectors of Covid-19 outbreak might affect the academic calendar, might reduce international students' enrolment, might experience a down-turn during the period of the Covid-19 outbreak for schools that depend more on foreign students for funding, schools may not be able to be liberal with their financial aid offerings; private school owners may find it difficult to pay the salaries of their employees during the period of the ravaging the Covid-19 pandemic. $^{3}$

The Covid-19 outbreak also caused educational institutions from all around the world have migrated from the traditional methods of learning to impart education

\footnotetext{
${ }^{1}$ Abayomi Baiyere and Hongxiu Li, "Application of a Virtual Collaborative Environment in a Teaching Case.," AMCIS $2016 \quad$ Proceedings, August 11, 2016, https://aisel.aisnet.org/amcis2016/ISEdu/Presentations/33.

${ }^{2}$ Bright Okanezi and Mercy Steve Amadi, "Examining The Ravaging COVID-19 And Its Implications For Educational Institutions On A Global Perspective," International Journal of Progressive Sciences and Technologies (I 25, no. 1 (2021): 227-34.

${ }^{3}$ Okanezi and Amadi.
} 
through online means or E-learning. ${ }^{4}$ E-learning has become quite popular among students across the world particularly, during the lockdown period due to the Covid-19 pandemic. ${ }^{5}$ Students in higher education with certain socio-demographic characteristics such as male students, part-time, first-level students, applied sciences, a lower living standard, and from Africa or Asia were significantly less satisfied with their academic work/life during the crisis. Whereas for female students, full-time, first-level students and students faced with financial problems were generally affected more by the pandemic in terms of their emotional life and personal circumstances. ${ }^{6}$

In Indonesia, It has been nearly 8 months since the coronavirus has affected Indonesia. The total number of Covid-19 cases in Indonesia up to now on November, 19, 2020 reaches 483.518 people. This virus has greatly increased since the announcement of the first patient on March 2, 2020. ${ }^{7}$ The rapid and sudden spread of the virus has forced the Indonesian government to close schools to limit massive physical contact and to save lives. Therefore, based on the Decree of Ministry of Education and Culture (MoEC) number 4 in the year 2020, the teaching and learning process was conducted online. There are several benefits in online learning such as easily accessible, relatively cheaper mode of education in terms of the lower cost of transportation, accommodation, and the overall cost of institution-based learning, flexible, and it can even reach rural and remote areas. ${ }^{8}$ Conversely, if the government has not been ready yet to do online learning, the learning that takes place online can hinder the teaching process and create imbalances when there is inadequate compatibility between technological design and psychological components required by the learning process; and inadequate adjustments to the learning process. ${ }^{9}$

There are also six factors used to measure E-Learning Readiness such as (1) students readiness, (2) teachers readiness, (3) infrastructure, (4) schools management,

\footnotetext{
${ }^{4}$ Vishal Dineshkumar Soni, "Global Impact of E-Learning during COVID 19," SSRN Electronic Journal, 2020, https://doi.org/10.2139/ssrn.3630073.

5 R Radha et al., "E-Learning during Lockdown of Covid-19 Pandemic: A Global Perspective," International Journal of Control and Automation 13, no. 4 (2020): 1088-99.

${ }^{6}$ Aleksander Aristovnik et al., "Impacts of the COVID-19 Pandemic on Life of Higher Education Students: A Global Perspective," preprint (Social Sciences, August 19, 2020), https://doi.org/10.20944/preprints202008.0246.v2.

${ }^{7}$ Dian Eka Nugraheny, "UPDATE: Bertambah 4.798, Kini Ada 483.518 Kasus Covid-19 di Indonesia," Kompas.com, November 19, 2020, https://nasional.kompas.com/read/2020/11/19/15163321/updatebertambah-4798-kini-ada-483518-kasus-covid-19-di-indonesia?page=all.

8 Shivangi Dhawan, "Online Learning: A Panacea in the Time of COVID-19 Crisis," Journal of Educational Technology Systems 49, no. 1 (September 2020): 5-22, https://doi.org/10.1177/0047239520934018.

${ }^{9}$ Dhawan.
} 
(5) schools culture, and (6) the tendency of face-to-face learning. Most schools in Indonesia are not ready to learn online. Teachers and students still need socialization and training on online learning. ${ }^{10}$ The online learning measurement has rarely been carried out simultaneously before. ${ }^{11}$ As a result, unpreparedness to learn online can decrease the quality of education directly. Inevitably, remote areas with very dense school-age populations are confused because of limited information technology. Nevertheless, there is no other choice except online learning. The teachers are not only demanded to master the material in offline classes, but also online classes. At this stage, the use of technology and online learning applications support. The teaching and learning process should be made interesting to reduce stress, fear, and anxiety levels of people. ${ }^{12}$

Previous studies have reported that various barriers discovered during the process of online teaching and learning. For the families who are living in rural areas, they are difficult to access online learning. For parents who are busy working outside the home, they are difficult to guide their children in online learning. The psychological condition of students who are accustomed to studying with teachers in the class must do online learning. It resulted in decreased student motivation, attention, enthusiasm, and achievement. ${ }^{13}$ The effectiveness of online learning is hampered by several factors such as (1) limitations of teachers and students' knowledge of the technology of information and qualification, ${ }^{14}$ (2) insufficient facilities and infrastructure, ${ }^{15}$ (3) limited and unstable internet access, ${ }^{16}$ and, (4) lack of readiness for budget provision. ${ }^{17}$ (5) the

\footnotetext{
${ }^{10}$ Samsul Jamal, "Analisis Kesiapan Pembelajaran E-Learning Saat Pandemi Covid-19 di SMK Negeri 1 Tambelangan," Jurnal Nalar Pendidikan 8, no. 1 (May 6, 2020): 16, https://doi.org/10.26858/jnp.v8i1.13561.

${ }^{11}$ Litao Sun, Yongming Tang, and Wei Zuo, "Coronavirus Pushes Education Online," Nature Materials 19, no. 6 (June 2020): 687-687, https://doi.org/10.1038/s41563-020-0678-8.

${ }^{12}$ Dhawan, "Online Learning."

13 Henry Aditia Rigianti, "Kendala Pembelajaran Daring Guru Sekolah Dasar Di Kabupaten Banjarnegara," Elementary School 7, no. 2 (July 2, 2020): 297-302.

${ }^{14}$ Nadia Fairuza Azzahra, "Mengkaji Hambatan Pembelajaran Jarak Jauh di Indonesia di Masa Pandemi Covid-19," Center for Indonesian Policy Studies (CIPS), Ringkasan Kebijakan No. 2, Mei 2020, 1-9.

15 Roman Andrianto Pangondian, Paulus Insap Santosa, and Eko Nugroho, "Faktor - Faktor Yang Mempengaruhi Kesuksesan Pembelajaran Daring Dalam Revolusi Industri 4.0," Seminar Nasional Teknologi Komputer \& Sains (SAINTEKS), January 2019, 56-60.

${ }^{16}$ Ericha Windhiyana, "Dampak Covid-19 Terhadap Kegiatan Pembelajaran Online Di Perguruan Tinggi Kristen Di Indonesia," Perspektif Ilmu Pendidikan 34, no. 1 (April 29, 2020): 1-8, https://doi.org/10.21009/PIP.341.1.

${ }^{17}$ Rizqon H Syah, "Dampak Covid-19 pada Pendidikan di Indonesia: Sekolah, Keterampilan, dan Proses Pembelajaran," SALAM: Jurnal Sosial dan Budaya Syar-i 7, no. 5 (April 14, 2020): 395-402, https://doi.org/10.15408/sjsbs.v7i5.15314.
} 
subsidized internet quota by the government to run the learning activities smoothly. ${ }^{18}$ It cannot be denied that parents, students, and teachers have an important role in the smooth running of online learning.

A lot of studies have explored the problems of online learning during the Covid19 pandemic start from elementary to university level. However, there is a notable paucity of similar research exploring online learning problems during the Covid-19 pandemic in the context of Santris or students in Islamic primary schools or Madrasah Ibtidaiyah. Nowadays, the rapid development of religion-based schools in Indonesia, especially Islam, also demands the importance of exploring online learning problems during the Covid-19 pandemic for Santri students at Madrasah Ibidaiyah level. Therefore, This study intended to explore the information of the obstacle factors in online learning and teaching activities at one of the largest Madrasah Ibtidaiyah during the Covid-19 pandemic in Yogyakarta. This research is expected to be one of the inputs in increasing the effectiveness of the implementation of online learning in Madarasah Ibtidaiyah during the Covid-19 pandemic and also as a recommendation in teaching and learning online in the future. Following were the basic research questions: ${ }^{19}$ What are the students' obstacles in online learning activities?, What are the parents' obstacles in online learning activities? and What are the teachers' obstacles in online learning activities?

\section{Methods}

This study was descriptive qualitative research using online survey method in the form of open-ended questionnaire. The participants of this study were students, parents and teachers at one of the largest Madrasah Ibtidaiyah in Yogyakarta. The followings were the participants background information.

\section{Participants' Status at School}

Related to participants' background information, asking the participants' status at school was to see the number of teachers and parents who participated in this study. The result indicated that there were 137 participants who were willing to be

\footnotetext{
${ }^{18}$ Alchamdani Alchamdani et al., "The Impact of Covid19 Pandemic on Online Learning Process in the College at Southeast Sulawesi," Jurnal Kesehatan Lingkungan 12, no. 1si (September 30, 2020): 129-36, https://doi.org/10.20473/jkl.v12i1si.2020.129-136.

19 Agus Purwanto et al., "Studi Eksploratif Dampak Pandemi COVID-19 Terhadap Proses Pembelajaran Online di Sekolah Dasar," EduPsyCouns Journal 2, no. 1 (2020): 1-12.
} 
interviewed. As seen in the diagram 1, there was $9.6 \%$ or 13 teachers and $90.4 \%$ or 123 students and parents participated in this study. Here was the diagram of participants' status at school.

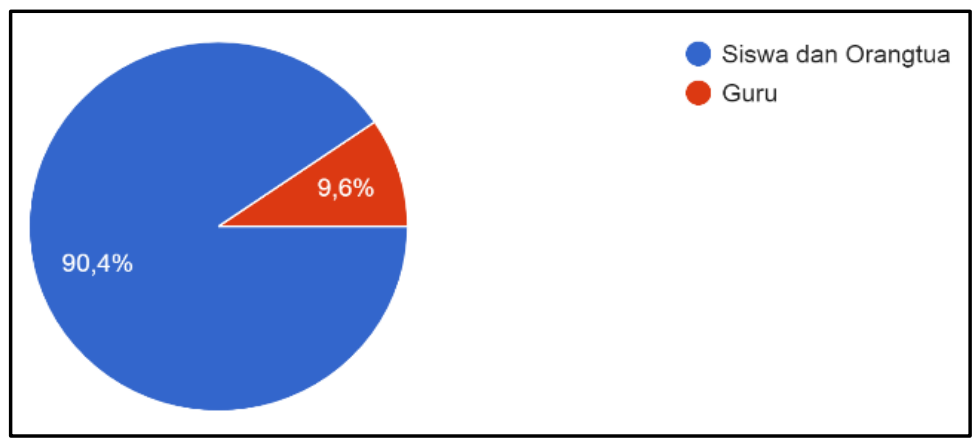

Diagram 1. Participants' Status at School

\section{Participants' Gender}

The second question of participants' background information was their gender. Asking the participants' gender at school was to see the dominant gender participating in this study. The diagram 2 showed that $75 \%$ participants was female and $25 \%$ participants was male. It meant that female is more participating than male.

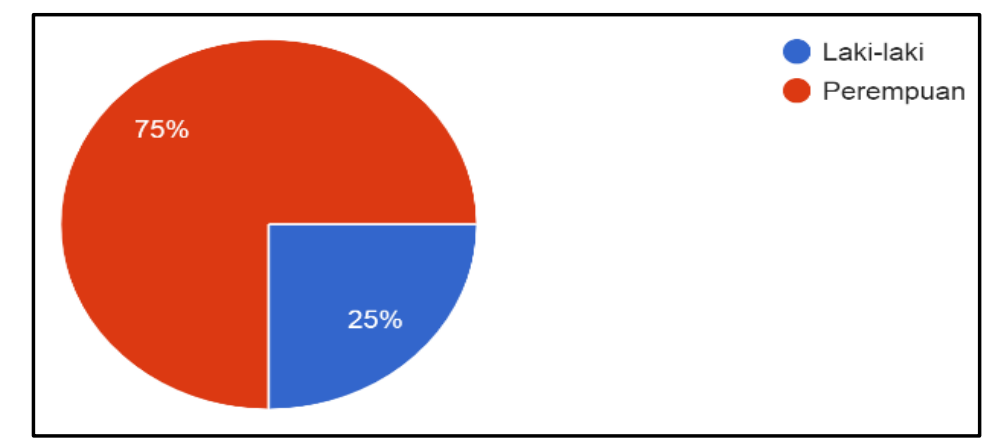

Diagram 2. Participants' Gender

In qualitative research, the intention of researcher is not to generalize from the sample to a population, but to explain, describe, and interpret. ${ }^{20}$ Sampling is not a matter of representative opinions, but a matter of information richness. ${ }^{21}$ In this study, there were 136 participants. The participants in this study were divided into two groups based on their status at school (as parents and as teachers). First, there were 123 parents

\footnotetext{
${ }^{20}$ Joseph Maxwell, “Qualitative Research Design : An Interactive Approach / J.A. Maxwell.," January 1, 2012.

21 Timothy Guetterman, "Descriptions of Sampling Practices Within Five Approaches to Qualitative Research in Education and the Health Sciences," Forum Qualitative Sozialforschung/Forum: Qualitative Social Research 16 (May 1, 2015).
} 
who were also willing to fill out the form (hereafter they were named as P1, P2, P3, P4, P5, and so on through P123). Second, there were 13 teachers who gave rich opinions (hereafter they were named as T1, T2, T3, T4, T5, and so on through T13). In collecting the data, the researcher asked a permission to the principal to conduct the research. Then, the researcher asked the teacher in charge to share the link of questionnare to all teachers and parents. After the data collected from the teachers and parents who are willing to fill out the questionnaire, the data were analyzed descriptively.

\section{Discussion}

\section{The Students and Parents' Obstacles in Online Learning}

There were 123 participants from parents who gave statements and opinions. The finding showed the kinds of obstacle factors faced the parents such as because of parents' work, limited parents' teaching knowledge, related to teaching materials, lack of budget for internet connection, limited Students' learning facility, and parents' difficulty in building students' motivation are the most factors that hinder the effectiveness of online learning. Those factors would be explained and discussed as follows.

\section{Parents' Work}

Related to the parents' work, many working parents had difficulty assisting the students in online learning. (P1) said that "Bagi orang tua yang bapak dan ibunya sama sama bekerja sangat sulit membagi waktu dan mendampingi anak belajar dan mengerjakan tugas yang harus di kirimkan”. "jika orangtuanya pas lagi ada kerjaan juga bingung bagi waktunya tapi yang di utamakan belajar anak dulu” (P18). Other participants added that "Waktunya terkadang bentrok dengan pekerjaan dan harus mengatur anak yang lagi bermain untuk belajar harus ngoyak-ngoyak anak dulu” (P21). "Waktu daring yang beberapa kali terganggu dengan kegiatan orang tua yang sedang bekerja” (P72). “Waktu untuk mengajar tidak banyak,karena pekerjaan rumah tangga dikejar kerjaan sampingan” (P101).

Participant (P115) also stated that "waktu dan proses pembelajaran bersamaan dengan pekerjaan orang tua”. "Mengajari anak tidak maksimal karena harus membagi waktu dengan pekerjaan rumah" (P106). "Karena orang tua sibuk jualan di warung, orang tua sering gak konsentrasi ngajari anak dalm belajar, anak juga kadang gak nurut kurang disiplin" (P123). Similar to previous participants, (P88) stated that 
"Orang tua yang bekerja di pertanian seperti sawah, perkebunan dan lain-lain atau berkerja di toko tidak bisa memantau setiap hari dan mendampingi anak-anak belajar di rumah". "Pendampingan saat mengerjakan tugas, sering bersamaan dengan tugas orangtua. karena orangtua juga mengajar daring” (P99). “Tidak bisa mendampingi anak dalam belajar karena harus bekerja karena saya single” (P118). The finding was in line with the previous studies that parents could not guide their children to study when they were working. ${ }^{22}$ Parents worked all day outside the home so they could only guide them at night. ${ }^{23}$

\section{Limited Parents' Teaching Knowledge}

The reality of parents in Indonesia do not entirely understand the use of technology, for example the parents who born before the 1980s and they are from less family income, they are really difficult to follow and assist their children to learn independently at home. The barriers of Information technology also play an important role of learning.

Related to the limitation of parents' knowledge participant (P4, P9, and P12) gave the statement that "Orang tua tidak mempunyai pengalaman dalam mengajar anak, pengetahuan orang tua terbatas, orang tua tidak memahami materi pelajaran, orang tua tidak maksimal dalam menyampaikan materi pelajaran”. It was also clearly explained by previous study stated that sometimes parents complained that they couldn't explain in detail to the students. ${ }^{24}$

\section{Related to Teaching Materials}

Related to the teaching materials, some problems found in this study. First, Students did not understand the materials given by the teachers. Several participants stated that "Murid lebih kesusahan dengan penjelasan lewat video atau voice not karena tidak bisa langsung bertanya dan melihat contoh secara jelas” (P85). "Kadang kesulitan dalam materi khususnya Bahasa arab, kadang anak protes karena kami terlalu protektif ke anak dalam mengerjakan tugas" (P37). Similar to previous

\footnotetext{
${ }^{22}$ Nindia Taradisa, "Kendala yang Dihadapi Guru Mengajar Daring Pada Masa Pandemi Covid-19 di Min 5 Banda Aceh," Kendala yang Dihadapi Guru Mengajar Daring Pada Masa Pandemi Covid-19 di Min 5 Banda Aceh, August 20, 2020, 1-11, https://repository.ar-raniry.ac.id/id/eprint/14083/.

${ }^{23}$ Andri Anugrahana, "Hambatan, Solusi dan Harapan: Pembelajaran Daring Selama Masa Pandemi Covid-19 oleh Guru Sekolah Dasar," Scholaria: Jurnal Pendidikan dan Kebudayaan 10, no. 3 (September 28, 2020): 282-89, https://doi.org/10.24246/j.js.2020.v10.i3.p282-289.

${ }^{24}$ Anugrahana.
} 
participants, "Cara pembelajarannya kurang maksimal" (P112) and "Kurang memahami materi yang ada" (51). Second, students did not focus on studying the materials (P12, P15, and P24). Third, students could not ask the teachers about the materials directly. The participants said that "Tidak bisa bertanya langsung dengan guru, ingin berangkat sekolah sudah bosan di rumah" (P52) and "Tidak dapat bertanya langsung kepada guru” (P49).

Forth, the teacher only gives assignments without explaining materials. Participants said that "Guru tidak mengajarkan materi dahulu sebelum memberikan tugas" (66). "terkadang guru juga hanya memberi tugas saja tanpa menjelaskan ke siswa" (70). "Tidak bisa bertatap muka dengan guru, tidak bisa bertanya secara langsung, kadang susah memahami” (105). Fifth, the teacher was unclear in explaining the materials (P53, P76, P83, P109, P113, and P115). Sixth, participants said that "Tidak terbiasa belajar materi secara online" (P69). The finding was supported by some previous studies stated that the students are difficult to understanding the materials and less interaction between teachers and students. ${ }^{25}$ The teachers also could not clearly explain the materials well. If students had never taken an online course, they were asked to predict how well their online learning would compare to a traditional class. $^{26}$

\section{Lack of Budget for Internet Connection}

Costs are also something that hinders online learning. A lot of teachers and parents do not have proper welfare and that is an important factor that hinders the smooth running of online learning. When they use the internet quota for meet the needs of online media, so obviously they are difficult to pay for it. The dilemma in using online learning also occurs, when the government always encourages productivity to move forward, but in other facts, teachers and parents have financial problems that actually have not been able to implement distance learning which requires large costs. As we all know, the government has not fully met the needs of these costs.

Related to the lack of budget for internet connection, some participants gave statements that "Harus menambah biaya untuk membeli kuota internet dan HP yang

\footnotetext{
25 Taradisa, "Kendala yang Dihadapi Guru Mengajar Daring Pada Masa Pandemi Covid-19 di Min 5 Banda Aceh."

${ }^{26}$ Lin Y. Muilenburg and Zane L. Berge, "Student Barriers to Online Learning: A Factor Analytic Study," Distance Education 26, no. $1 \quad$ (January 2005): 29-48, https://doi.org/10.1080/01587910500081269.
} 
mendukung. Orangtua juga harus bisa mengikuti perangkat tehnologi online” (P14). "kendala lagi tentang biaya untuk beli kuota, karena pandemi ini saya tidak kerja dan hanya suami yang kerja jadi uang lebih diutamakan untuk kebutuhan pokok” (P31). Other participants added that "Pembelian kuota internet yang terus menerus (P76). karena kami yang ekonomi menengah ke bawah harus lebih banyak pengeluaran untuk soal kuota (P75). kuota internet yg semakin melonjak naik (P92). The result was in line with previous studies said that internet usage will increase the expenses of parents and online learning consumed a lot of internet quota. ${ }^{27}$

\section{Limited Students' Learning Facility}

In online learning, it is undeniable that the use of technological tools such as computers, laptops and hand phone is very important. At least students must have one of these tools to be able to learn cellphone examples. As we all know, this device is not cheap. For parents who have middle and high-income, there is no problem with that. Nevertheless for low-income parents, facilitating their children with hand phone is a challenge. Not even a few of them study at home with friends who have hand phone to follow online lessons. Likewise with honorary teachers, ws we know that a lot of Indonesian teachers are still in a dire economic condition. Teachers and students welfare who limit them from being completely limited in enjoying information technology facilities and infrastructure that are indispensable nowadays.

Related to the limited parents' learning facility, some problems found in this study. First, Mobile phone's memory was full (P88, P107, and P116). Second, Students could not use their own cellphone yet (P77, P82). Third, Internet quota was wasteful and run out quickly (P78, P89, and P99). Forth, Internet connection was not stable (P83, P95, P111). ". The finding was also clearly explained by previous studies said that some students in rural areas with poor family conditions do not have access to online learning. ${ }^{28}$ In Indonesia, internet network was not evenly distributed and it was not in all both primary and secondary schools that were able to enjoy the internet. For those who

\footnotetext{
27 Taradisa, "Kendala yang Dihadapi Guru Mengajar Daring Pada Masa Pandemi Covid-19 di Min 5 Banda Aceh."

${ }^{28}$ Rigianti, "Kendala Pembelajaran Daring Guru Sekolah Dasar Di Kabupaten Banjarnegara.” 
had the internet connection, they had to work hard to utilize the device maximaly. ${ }^{29}$ They also felt confused about e-learning. ${ }^{30}$

\section{Parents' Difficulty in Building Students' Motivation}

Related to parents' difficulty in building students' motivation. This study found some problems. First, students preferred to play (P39, P108, and P117). Second, Students did not obey their parents (P72). Other participants also added that parents should be patient (P66). Parents were difficult to make students more enthusiastic in learning (P39). Students were lack of discipline in learning (P51). This result was supported by the previous studies stated that the students' motivation is not stable. ${ }^{31}$ Students sometimes do not obey their parents like when taught by teachers at school. ${ }^{32}$ Online learning was less effective because there were reasons for students who did not have a network, no devices such as hand phone or laptops. ${ }^{33}$ Students felt bored studying at home ${ }^{34}$ and the decreased interest and learning motivation. ${ }^{35}$

\section{The Teachers' Obstacles in Online Learning}

Online learning becomes a must during this pandemic. The teachers must implement online learning to prevent the spread of covid-19. The findings showed the problems that hinder the effectiveness of online learning such as inadequate teachers' facilities conducting online learning, teachers' demand to create creative and inovative teaching materials, and limited parents' knowledge of technology. They will be explained and discussed as follows.

\section{Inadequate Facilities}

Internet network is still uneven in Indonesia. The internet cannot be enjoyed by all educational institutions in Indonesia, both in primary and secondary schools.

\footnotetext{
${ }^{29}$ Syah, "Dampak Covid-19 pada Pendidikan di Indonesia."

${ }^{30}$ Sutri Windiarti et al., "Teachers' Perception toward the Obstacles of E-Learning Classes," Ethical Lingua: Journal of Language Teaching and Literature 6, no. 2 (September 4, 2019): 117-28, https://doi.org/10.30605/25409190.v6.117-128.

${ }^{31}$ Windiarti et al.

${ }^{32}$ Anugrahana, "Hambatan, Solusi dan Harapan."

${ }^{33}$ Taradisa, "Kendala yang Dihadapi Guru Mengajar Daring Pada Masa Pandemi Covid-19 di Min 5 Banda Aceh."

${ }^{34}$ Anugrahana, "Hambatan, Solusi dan Harapan."

${ }^{35}$ Novi Rosita Rahmawati, Fatimatul Eva Rosida, and Farid Imam Kholidin, "Analisis Pembelajaran Daring Saat Pandemi di Madrasah Ibtidaiyah," SITTAH: Journal of Primary Education 1, no. 2 (October 31, 2020): 139-48, https://doi.org/10.30762/sittah.v1i2.2487.
} 
Although internet network connection is available, many students are not able to access online materials smoothly due to the limited network connection.

Related to facilities, participant (T1) gave statement that "Full memory HP, HP ngedrop, jika video, tidak bisa terkirim dengan utuh". Some teachers gave opinion that sending text is easier than sending picture or video messages. ${ }^{36}$ Other participants also gave statements that "Gangguan sinyal dan kadang miskomunikasi, Koneksi internet yang kurang bersahabat" (T2). Pratiwi stated that "Internet yang kurang mendukung pembelajaran online adalah salah satu kendala dalam pelaksanaan pembelajaran daring". As we know that internet connection is an essential role in online learning. Teachers and students will have no problems with internet connection if the connection can run stably and effectively. ${ }^{37}$ "Waktu kerja menjadi 24 jam dan rasa malas yang berlebihan" (T7). The result was in line with the previous study stated that the teachers were still difficult to manage the time. ${ }^{38}$ Not all Indonesian teachers understand the use of technology. ${ }^{39}$ It was difficult to apply because online learning is something new right now. The teachers thought that online learning is still something new in Indonesia, and they still do not realize the important of the technology to smooth online learning. The teachers are also not ready to apply the kinds of useful technology and applications supporting the learning process. ${ }^{40}$

\section{Teachers' Demand to Create Creative Teaching Materials}

The sudden shift from face-to-face in the classroom to online learning at home needs for increased teacher teaching quality and the teachers conveyed that they were not ready for this rapid change. Related to materials, participant (T3) gave the statement that “Guru harus lebih aktif, kreatif dan inovatif dalam pembelajaran online. This finding is supported by previous studie stated that teachers need to be creative in creating the attractive online learning materials for students. ${ }^{41}$ Teachers only facilitate class libraries, modules, textbooks, and supporting books, and most importantly internet access, as well as providing several computers for students who do not carry laptops. ${ }^{42}$

\footnotetext{
${ }^{36}$ Rigianti, "Kendala Pembelajaran Daring Guru Sekolah Dasar Di Kabupaten Banjarnegara."

${ }^{37}$ Windiarti et al., "Teachers' Perception toward the Obstacles of E-Learning Classes."

${ }^{38}$ Windiarti et al.

${ }^{39}$ Syah, "Dampak Covid-19 pada Pendidikan di Indonesia."

${ }^{40}$ Windiarti et al., "Teachers' Perception toward the Obstacles of E-Learning Classes."

${ }^{41}$ Anugrahana, "Hambatan, Solusi dan Harapan."

42 Daniel S Tjandra, "Impelementasi Pembelajaran Pendidikan Agama Kristen di Abad 2," Jurnal Pendidikan Agama Kristen 1, no. 1 (2020): 1-10.
} 
Some participants also gave statements that "Keterbatasan dalam menjelaskan materi khususnya materi berhitung karena tidak bertatap muka secara langsung sehingga tidak bisa mengukur pemahaman siswa" (T5). "Kurang maksimalnya penyampaian materi and anak-anak kurang termotivasi” (T8, T9, T10). This finding was also clearly explained by previous studies stated that the materials were not effective enough because they were taught through video, photo or written summary. ${ }^{43}$ Therefore, the students felt difficult to understand the materials. The difficulties of the teachers in online learning are also influenced by the unequal competence of ICT in Indonesia. There are gaps in the quality of education across regions in Indonesia, especially between Java and outside Java, ${ }^{44}$ and between socio-economic conditions. ${ }^{45}$

\section{Limited Parents' Knowledge of Technology}

Related to the parents' knowledge about the use of smartphone and the use of online learning applications support, participant (T4) gave the statement that "Kesulitan dalam mengajarkan materi karena terbentur dengan memori handphone para wali, jadi hanya melalui voice note tanpa video. (T6) "Keterbatasan resources dari wali murid (misalnya: tidak semua orangtua bisa mengunakan google form/meet/hangout) dll”. This result was in line with previous study stated that some parents were not familiar with technology. ${ }^{46}$

\section{Conclusion}

The process of online learning on the pandemic Covid-19 in Madrasah Ibtidaiyah still has some obstacles in its implementation. In terms of students, most of them preferred to play to study, students were difficult to understand the materials given by the teachers, and they were lack of discipline in learning and felt bored studying at home. In terms of parents, some problems were found in online learning. Those who had to work outside the home could not guide their children, some of them had difficulty to explaining the materials for their children, parents were also difficult to make students more enthusiastic in learning, parents' lack of budget for internet

${ }^{43}$ Taradisa, "Kendala yang Dihadapi Guru Mengajar Daring Pada Masa Pandemi Covid-19 di Min 5 Banda Aceh."

${ }^{44}$ Yuni Azzizah, "Socio-Economic Factors on Indonesia Education Disparity," International Education Studies 8, no. 12 (November 26, 2015): 218-30, https://doi.org/10.5539/ies.v8n12p218.

45 Tatang Muttaqin, "Determinants of Unequal Access to and Quality of Education in Indonesia," Jurnal Perencanaan Pembangunan: The Indonesian Journal of Development Planning 2, no. 1 (March 27, 2018): 1-23, https://doi.org/10.36574/jpp.v2i1.27.

${ }^{46}$ Anugrahana, "Hambatan, Solusi dan Harapan." 
connection, internet connection was not stable, difficulty in building students' motivation, and parents had limited knowledge of technology.

Whereas, the most obstacles factors on online learning in terms of teachers such as inadequate online learning facilities for example handphone memory was full, internet connection was not stable, and uncertain working time, teachers were demanded to create creative teaching materials. Dealing with those online learning problems faced by students, parents, and teachers in Islamic primary school or Madrasah Ibtidaiyah, parents must control their children's learning activities during online learning. Parents must wisely apply learning rules to their children so that they are disciplined in learning at home, such as making flexible learning schedules but still regular like studying at school.

To overcome the parents' difficulty explaining a certain learning materials being studied for their children, parents have to actively consult with teachers or find appropriate sources. Parents also are able to take advantage of online learning media that has been provided by the Ministry of Education and Culture (MoEC) that provide free access to enrich learning sources. Creating a comfortable learning atmosphere such as giving freedom and flexibility to children to explore what they want, trying to learn outdoor, and interspersed with fun activities are essential methods to kill children boredom in online learning.

To overcome teachers and parents' lack of budget for internet connection because of low-income, The government through MoEC has provided free internet access to teachers and students starting from early childhood education/Pendidikan Anak Usia Dini (PAUD) to university levels. If there is problem with the free internet access from MoEC, it is recomended to utilize the Funds of School Operational Assistance (Bantuan Operasional Sekolah/BOS) to support their finance in an emergency situation like now in the pandemic situation.

In terms of the lack of teachers' quality teaching materials and the use of technology in teaching online, teachers need to have not only basic technology skills (such as using computers and being connected to the internet), but also knowledge for using recording devices and software, as well as methods for delivering lessons without face-to-face interaction. Therefore, attention to this, it is important to include online learning skills in long term teacher education program (Pendidikan Profesi Guru/PPG). Therefore, after this pandemic of Covid-19 ends, the online learning system can be used as a model for further learning. 


\section{References}

Alchamdani, Alchamdani, Fatmasari Fatmasari, Eka Rahmadani Anugrah, Nahda Putri Sari, Freddrika Putri, and Astina Astina. "The Impact of Covid19 Pandemic on Online Learning Process in the College at Southeast Sulawesi." Jurnal Kesehatan Lingkungan 12, no. 1si (September 30, 2020): 129-36. https://doi.org/10.20473/jkl.v12i1si.2020.129-136.

Anugrahana, Andri. "Hambatan, Solusi dan Harapan: Pembelajaran Daring Selama Masa Pandemi Covid-19 oleh Guru Sekolah Dasar." Scholaria: Jurnal Pendidikan dan Kebudayaan 10, no. 3 (September 28, 2020): 282-89. https://doi.org/10.24246/j.js.2020.v10.i3.p282-289.

Aristovnik, Aleksander, Damijana Keržič, Dejan Ravšelj, Nina Tomaževič, and Lan Umek. "Impacts of the COVID-19 Pandemic on Life of Higher Education Students: A Global Perspective." Preprint. Social Sciences, August 19, 2020. https://doi.org/10.20944/preprints202008.0246.v2.

Azzahra, Nadia Fairuza. "Mengkaji Hambatan Pembelajaran Jarak Jauh di Indonesia di Masa Pandemi Covid-19." Center for Indonesian Policy Studies (CIPS), Ringkasan Kebijakan No. 2, Mei 2020, 1-9.

Azzizah, Yuni. "Socio-Economic Factors on Indonesia Education Disparity." International Education Studies 8, no. 12 (November 26, 2015): 218-30. https://doi.org/10.5539/ies.v8n12p218.

Baiyere, Abayomi, and Hongxiu Li. "Application of a Virtual Collaborative Environment in a Teaching Case." AMCIS 2016 Proceedings, August 11, 2016. https://aisel.aisnet.org/amcis2016/ISEdu/Presentations/33.

Dhawan, Shivangi. "Online Learning: A Panacea in the Time of COVID-19 Crisis." Journal of Educational Technology Systems 49, no. 1 (September 2020): 5-22. https://doi.org/10.1177/0047239520934018.

Dian Eka Nugraheny. "UPDATE: Bertambah 4.798, Kini Ada 483.518 Kasus Covid-19 di Indonesia." Kompas.com, November 19, 2020. https://nasional.kompas.com/read/2020/11/19/15163321/update-bertambah4798-kini-ada-483518-kasus-covid-19-di-indonesia?page=all.

Guetterman, Timothy. "Descriptions of Sampling Practices Within Five Approaches to Qualitative Research in Education and the Health Sciences." Forum Qualitative Sozialforschung/Forum: Qualitative Social Research 16 (May 1, 2015).

Jamal, Samsul. "Analisis Kesiapan Pembelajaran E-Learning Saat Pandemi Covid-19 di SMK Negeri 1 Tambelangan.” Jurnal Nalar Pendidikan 8, no. 1 (May 6, 2020): 16. https://doi.org/10.26858/jnp.v8i1.13561.

Maxwell, Joseph. "Qualitative Research Design: An Interactive Approach / J.A. Maxwell.," January 1, 2012.

Muilenburg, Lin Y., and Zane L. Berge. "Student Barriers to Online Learning: A Factor Analytic Study." Distance Education 26, no. 1 (January 2005): 29-48. https://doi.org/10.1080/01587910500081269.

Muttaqin, Tatang. "Determinants of Unequal Access to and Quality of Education in Indonesia." Jurnal Perencanaan Pembangunan: The Indonesian Journal of Development Planning 2, no. 1 (March 27, 2018): 1-23. https://doi.org/10.36574/jpp.v2i1.27. 
Okanezi, Bright, and Mercy Steve Amadi. "Examining The Ravaging COVID-19 And Its Implications For Educational Institutions On A Global Perspective." International Journal of Progressive Sciences and Technologies (I 25, no. 1 (2021): 227-34.

Pangondian, Roman Andrianto, Paulus Insap Santosa, and Eko Nugroho. "Faktor Faktor Yang Mempengaruhi Kesuksesan Pembelajaran Daring Dalam Revolusi Industri 4.0." Seminar Nasional Teknologi Komputer \& Sains (SAINTEKS), January 2019, 56-60.

Purwanto, Agus, Rudy Pramono, Masduki Asbari, Priyono Budi Santoso, Laksmi Mayesti, Choi Chi Hyun, and Ratna Setyowati Putri. "Studi Eksploratif Dampak Pandemi COVID-19 Terhadap Proses Pembelajaran Online di Sekolah Dasar." EduPsyCouns Journal 2, no. 1 (2020): 1-12.

Radha, R, K Mahalakshmi, Dr V Sathish Kumar, and Dr AR Saravanakumar. "ELearning during Lockdown of Covid-19 Pandemic: A Global Perspective." International Journal of Control and Automation 13, no. 4 (2020): 1088-99.

Rahmawati, Novi Rosita, Fatimatul Eva Rosida, and Farid Imam Kholidin. "Analisis Pembelajaran Daring Saat Pandemi di Madrasah Ibtidaiyah." SITTAH: Journal of Primary Education 1, no. 2 (October 31, 2020): 139-48. https://doi.org/10.30762/sittah.v1i2.2487.

Rigianti, Henry Aditia. "Kendala Pembelajaran Daring Guru Sekolah Dasar Di Kabupaten Banjarnegara.” Elementary School 7, no. 2 (July 2, 2020): 297-302.

Soni, Vishal Dineshkumar. "Global Impact of E-Learning during COVID 19." SSRN Electronic Journal, 2020. https://doi.org/10.2139/ssrn.3630073.

Sun, Litao, Yongming Tang, and Wei Zuo. "Coronavirus Pushes Education Online." Nature Materials 19, no. 6 (June 2020): 687-687. https://doi.org/10.1038/s41563-020-0678-8.

Syah, Rizqon H. "Dampak Covid-19 pada Pendidikan di Indonesia: Sekolah, Keterampilan, dan Proses Pembelajaran." SALAM: Jurnal Sosial dan Budaya $\begin{array}{lllll}\text { Syar-i } & 7, \quad \text { no. } 5 \text { (April 14, 2020): 395-402. }\end{array}$ https://doi.org/10.15408/sjsbs.v7i5.15314.

Taradisa, Nindia. "Kendala yang Dihadapi Guru Mengajar Daring Pada Masa Pandemi Covid-19 di Min 5 Banda Aceh." Kendala yang Dihadapi Guru Mengajar Daring Pada Masa Pandemi Covid-19 di Min 5 Banda Aceh, August 20, 2020, 1-11. https://repository.ar-raniry.ac.id/id/eprint/14083/.

Tjandra, Daniel S. "Impelementasi Pembelajaran Pendidikan Agama Kristen di Abad 2." Jurnal Pendidikan Agama Kristen 1, no. 1 (2020): 1-10.

Windhiyana, Ericha. "Dampak Covid-19 Terhadap Kegiatan Pembelajaran Online Di Perguruan Tinggi Kristen Di Indonesia.” Perspektif Ilmu Pendidikan 34, no. 1 (April 29, 2020): 1-8. https://doi.org/10.21009/PIP.341.1.

Windiarti, Sutri, Nurul Fadilah, Eka Dhermawati, and Bambang Widi Pratolo. "Teachers' Perception toward the Obstacles of E-Learning Classes." Ethical Lingua: Journal of Language Teaching and Literature 6, no. 2 (September 4, 2019): 117-28. https://doi.org/10.30605/25409190.v6.117-128. 